\title{
Bio-fertilizers' protocol for controlling root knot nematode Meloidogyne javanica infecting peanut fields
}

\author{
Hamida Ahmed Osmann ${ }^{1}$, Hoda Hussein Ameen ${ }^{1 *}$, Moawad Mohamed ${ }^{1}$, Ghada M. El-Sayed ${ }^{2}$, \\ Mona Gergis Dawood ${ }^{3}$ and Usama Samy Elkelany ${ }^{1}$
}

\begin{abstract}
Background: Plant parasitic nematodes create serious threat to crop production. In Egypt root knot nematode, Meloidogyne spp. has been considered to be a limiting factor in the production of most crops of which the Peanut (Arachis hypogaea L.) is an important legume and oil crop. Therefore, management of root knot nematodes Meloidogyne spp. is an obligatory challenge. Microbial organisms are extensively used as eco-friendly tools for controlling plant parasitic nematodes as alternative to chemical nematicides. The effectiveness of the commercial bacterial bio-fertilizers NPK containing Bacillus polymyxa, B. circulance, B. megaterium, Pseudomans spp.; the nitrogen fixative bacteria Azotobacter chroocoocum and the bacterial isolate NRC211 were evaluated against the root knot nematode, Meloidogyne javanica infecting peanut plants under field conditions. Identification of the bacterial isolate was made through PCR amplification and sequencing of 165 rDNA gene.

Results: Sequencing of 165 rDNA gene revealed that the bacterial isolate NRC211 had 100\% similarity with Bacillus wiedmannii strain FSL W8-0169 16S ribosomal RNA. This Bacillus was recorded for the first time under accession number LC626774 on GenBank data base as B. wiedmannii NRC211. Recorded data revealed that all the tested treatments whether single or combined in soil naturally infested with M. javanica, resulted in variable significant reduction in the nematode reproductive parameters with a considerable increase in crop production and oil content of peanut plant. These results were improved by increasing the frequency of application of the bio-agents. In this respect the repeated combined treatment of A. chroococcum and B. wiedmannii NRC211 treatment overwhelmed all other treatments in decreasing nematode reproductive parameters with percentage reductions of $94.8,79.0$ and $80.1 \%$ in $M$. javanica juveniles in soil, galls and egg masses, respectively. This was associated with slight increase in peanut oil content than the untreated control. The repeated combined treatment of NPK plus A. chroococcum produced the highest increase $608.7 \%$, and $72.7 \%$ in crop production and plant growth parameters, respectively than the control. While, the oil content in this treatment was increased up to $47.4 \mathrm{~g} / \mathrm{kg}$.
\end{abstract}

Conclusion: It was concluded that B. wiedmanni NRC211 is an eco-friendly bio agent that can be applied with other commercial microbial bio-fertilizers in bio-integrating programs for controlling M. javanica infecting peanut plants.

Keywords: Biocontrol, Bacillus wiedmannii NRC211, Azotobater chroococcum, Meloidogyne javanica, Peanut plant, Microbial fertilizers

\footnotetext{
*Correspondence: hoda_ameen@yahoo.co.uk

1 Plant Pathology Department, National Research Center, Giza, Egypt Full list of author information is available at the end of the article
}

\section{Background}

Plant parasitic nematodes create a serious threat to crop production. Root knot nematode of the genus Meloidogyne is recognized as the major cause of decreasing crop's 
productivity (Khan et al. 2010). In Egypt, the root knot nematode Meloidogyne spp. have been considered to be a limiting factor in the production of most crops (Abdelgawad 2014). Of which, Peanut (A. hypogaea L.) is an important legume and oil crop. Several species of root knot nematodes are found to infest peanut plants e.g. M. arenaria Ibrahim and Mokbel (2009) and M. javanica (Osman et al. 2019). Therefore, management of root knot nematodes Meloidogyne spp. is an obligatory challenge. The control method based on application of chemical nematicides is now limited due to concerns regarding ecological risks (Moosavi and Zare 2012). Application of eco-friendly agents such as plant growth-promoting rhizobacteria (PGPR) to avoid the hazard effects of chemical nematicides are now in progress. The most dominant known genera of PGPR are Pseudomonas and Bacillus spp. for controlling nematodes (Vejan et al. 2016). Among these, Pseudomonas flurorescens has been extensively exploited for the suppression of root knot nematodes Meloidogyne spp. and improving yield (Haseeb and Khan 2012). Bacillus spp. are another group of bacterial agents that have been recognized as one of the most promising groups of nematode antagonists e.g. B. cereus, B. megaterium that have been found to be important for effective management of root knot nematodes and enhancing crop production (El-Wakeel et al. 2020). Similarly, B. megaterium decreased root knot nematodes infection and enhanced crop production (Mostafa et al. 2018). Based on molecular identification 6 bacterial isolates were identified. B. wiedmannii had the best results in reducing all nematode reproductive parameters and enhancing plant growth. Azotobacter is a free living nitrogen fixative plant growth-promoting rhizobacteria that enhance emerging colonized roots, and stimulate overall plant growth. Siddiqui and Mohamed (2001) reported that manipulating crop rhizosphere by inoculation with Azotobacter for controlling root knot nematode showed considerable promising results. Bansal and Verma (2002) investigated the effects of $A$. chroococcum inoculation on root invasion and reproductive potential of $M$. javanica. They revealed that A. chroococcum inhibited nematode development and multiplication in the plant.

This study was conducted in order to assess the efficacy of 3 bacterial bio- agents viz: NPK as standard microbial fertilizer, A. chroococcum as a nitrogen fixing bacterium, and $B$. wiedmannii singly or in combination for the management of $M$. javanica, the growth and the yield production of peanut (A. hypogaea L.) under field conditions.

\section{Methods}

\section{Source of seeds}

Seeds of the peanut (A. hypogaea L.) cv. Giza 6 were obtained from the Department of Horticulture Research Centre, Agriculture Research Center, Giza, Egypt.

\section{Experimental field}

The selected field was naturally infested with root knot nematode $M$. javanica, a causal pathogen of peanut plant. The roots of peanut plants previously planted in the area were collected, and the adult females were removed from their egg masses to identify the nematode species by the morphological characteristics according to the female perennial pattern (Taylor and Sasser 1978). Initial population densities of nematodes were determined as described under experimental design section.

\section{Sources of bio-agents}

- NPK, a standard microbial fertilizer containing 4 microorganisms viz; $B$. polymyxa, B. megaterium, $B$. circulance and Pseudomonas sp. was purchased from a commercial office of the Ministry of Agriculture, Giza, Egypt.

- A. chroococcum Az, a commercial liquid preparation purchased from a commercial office of the Ministry of Agriculture, Giza Egypt.

- Rhizobacterium was isolated from soil samples adhering to peanut plants from the previous peanut crop in the same experimental field. Identification was made through PCR amplification and sequencing of $16 \mathrm{~s}$ rDNA gene.

\section{Isolation of bacterial strain}

The soil samples ( $5 \mathrm{~g}$ each) were serially diluted in saline $(0.85 \%, \mathrm{NaCL} w / \mathrm{v})$, spread and plated in triplicate on Luria- Bertani (LB) medium (Davis et al. 1980), agar medium (Atlas 1995), followed by incubation at $30^{\circ} \mathrm{C}$ for $48 \mathrm{~h}$.

\section{Extraction of genomic DNA from bacterial isolate}

A single colony of bacterial isolate NRC211 was cultured in a conical flask containing $20 \mathrm{ml}$ of LB medium (Davis et al. 1980). The culture was centrifuged at $13,000 \mathrm{rpm}$ for 5 min at $4{ }^{\circ} \mathrm{C}$. The pellet was subjected to genomic DNA extraction using the (QIAamp DNA Mini Kit, QIAGEN, Germany). The extracted DNA was used as a template for PCR to amplify the $16 \mathrm{~S}$ rDNA gene, using the universal primers; forward primer sequence (5'AGAGTT TGATCCTGGCTCAG3') and reverse primer sequence (5'CTACGGCTACCTTGTTACGA3'), thereby producing an amplicon of $\sim 1500$ bp (Ghada et al. 2018). PCR products were purified by QIAquick PCR Purification Kit (Germany), following resolving by electrophoresis on $1 \%$ agarose gels and compared to a $1 \mathrm{~kb}$ DNA ladder (Thermoscientific, USA). For sequencing, $16 \mathrm{~s} \mathrm{rDNA}$ gene was sent to Clinilab, Egypt. Obtained sequence was aligned against data base deposited in NCBI. 
Bacterial isolate was stored on LB slants and maintained in Nematology Lab., Plant Pathology Dept., National Research Center, Giza, Egypt. A conical flask ( $250 \mathrm{ml}$ ) of LB broth medium was inoculated by bacterial isolate and incubated at $30 \mathrm{C}^{\circ}$ with shaking at $150 \mathrm{rpm}$ for $48 \mathrm{~h}$. prior to application.

\section{Assay of protease activity}

Proteolytic activity of bacteria was assessed according to method described by Han and Damodaran (1997) with a slight modification. An inoculum was obtained by culturing one colony of bacterial strain grown on plate count agar in tryptic soya broth (Sigma Aldrich) for $24 \mathrm{~h}$ at $180 \mathrm{rpm}$. One unit of protease activity was defined as the amount of enzyme needed to release $1 \mu \mathrm{g}$ of tyrosine per $\mathrm{min} / \mathrm{ml}$ under the assay conditions.

\section{Experimental design and treatments}

A field experiment was carried out during June-October 2019 at Kafr-Hakim village, Giza Governorate, Egypt. The experimental area, naturally infested with $M$. javan$i c a$, was divided into 3 plots, each comprising 8 rows (6 m. long and $50 \mathrm{~cm}$ width), and the distance of $(15 \mathrm{~cm})$ between plants. The experiment was set up in a completely randomized block design with 8 treatments; each treatment was replicated 3 times. The treatments were: A- single treatments: 1-the standard microbial fertilizer containing B. polymyxa, B. megaterium, B. circulance and Pseudomonas sp. (NPK), 2- A. chroococcum (Az), 3- B. wiedmannii NRC211 (Bw). B- Combined treatments: 4$\mathrm{Az}+\mathrm{Bw}, 5-\mathrm{NPK}+\mathrm{Az}, 6-\mathrm{NPK}+\mathrm{Bw}, 7-\mathrm{NPK}+\mathrm{Az}+\mathrm{Bw}$, and 8- Infected untreated (negative control). The frequency of application of the tested bio agents in each bio agent-allocated area were: 1- At planting time, 2- At planting time and after one month, 3- At planting time and after 2 months, respectively. The doses were: $50 \mathrm{ml}$ from B. wiedmannii NRC211 concentration $\left(2 \times 10^{6} \mathrm{cfu} /\right.$ $\mathrm{ml}$ were added at each time/hill). A. chroococcum: $50 \mathrm{ml}$ from the commercial liquid preparation were added at each time/hill. NPK: $50 \mathrm{ml}$ were added at each time/hill. Initial population densities of $M$. javanica were determined at planting time according to Barker (1985) from $250 \mathrm{~g}$ subsamples of well mixed soil from each row and then, all the 3 plots were treated by the bio control agents according to the allocated area for each treatment. After one month, the population densities were determined in all the 3 plots. Only plots 2 and 3 were treated with the bio-control agents. After 2 months, population densities were determined as previously mentioned in all plots, here only plot 3 was treated with the bio- control agents. Four months later, at harvest time, 5 peanut plants were chosen at random from each treatment-allocated area, pods were hand harvested for yield estimation and recorded in terms of their average weights. Other plant growth parameters such as fresh and dry weights, number and weight of pods, weight of 200 seeds were recorded. The oil content of peanut seeds was determined according to the procedure reported by the American Association of Analytical Chemists (AOAC 2020) and was recorded in terms of percentage wt./wt. For evaluation of nematode reproductive parameters, the numbers of root galls and egg masses $/ 5 \mathrm{~g}$ roots were recorded. Final nematode soil population was extracted and densities of $M$. javanica were determined and expressed as the number of juveniles/250 g soil. Percentage nematode reduction was determined according to Henderson and Tilton formula (Puntener 1981) as follows:

$$
\begin{aligned}
& \text { Nematode reduction } \% \\
& \quad=\{1-(\mathrm{PTA} / \mathrm{PTB} \times \mathrm{PCB} / \mathrm{PCA})\} \times 100,
\end{aligned}
$$

where $\mathrm{PTA}=$ population in treated plot after application, $\mathrm{PTB}=$ population in treated plot before application, $\mathrm{PCB}=$ population in check plot before application and $\mathrm{PCA}=$ population in check plot after application.

\section{Statistical analysis}

All obtained data were subjected to proper statistical of variance according to Snedecor and Cochran (1980), using Assistat program version 7.6 beta. The means values were compared using Duncan (1955) Multiple Range Test at $P \leq 0.05$ level.

\section{Results}

Molecular identification of isolated bacterial strain

The universal primers of $16 \mathrm{~s}$ rDNA gene amplified $\sim 1550$ bp (Fig. 1) for the bacterial isolate. Partial DNA sequence was subjected to BLAST search on https://blast.ncbi.nlm.nih.gov/Blast against the available sequences deposited in NCBI database, $16 \mathrm{~S}$ rDNA gene sequence of bacterial isolate scored $100 \%$ with $B$. wiedmannii strain FSL W8-0169 16S ribosomal RNA. This isolate was recorded at GenBank data base as B. wiedmannii NRC211 under accession number LC626774

\section{Protease activity of the bacterial strain}

The results showed that $B$. wiedmannii NRC211 protease activity was $1.17 \mu \mathrm{g}$ tyrosine released $/ \mathrm{min} / \mathrm{ml}$. under the assay conditions.

\section{Effect of application frequency of different bio agents on nematode Meloidogyne javanica reproductive parameters}

Recorded data revealed that all tested treatments, whether single or in combination resulted in variable 


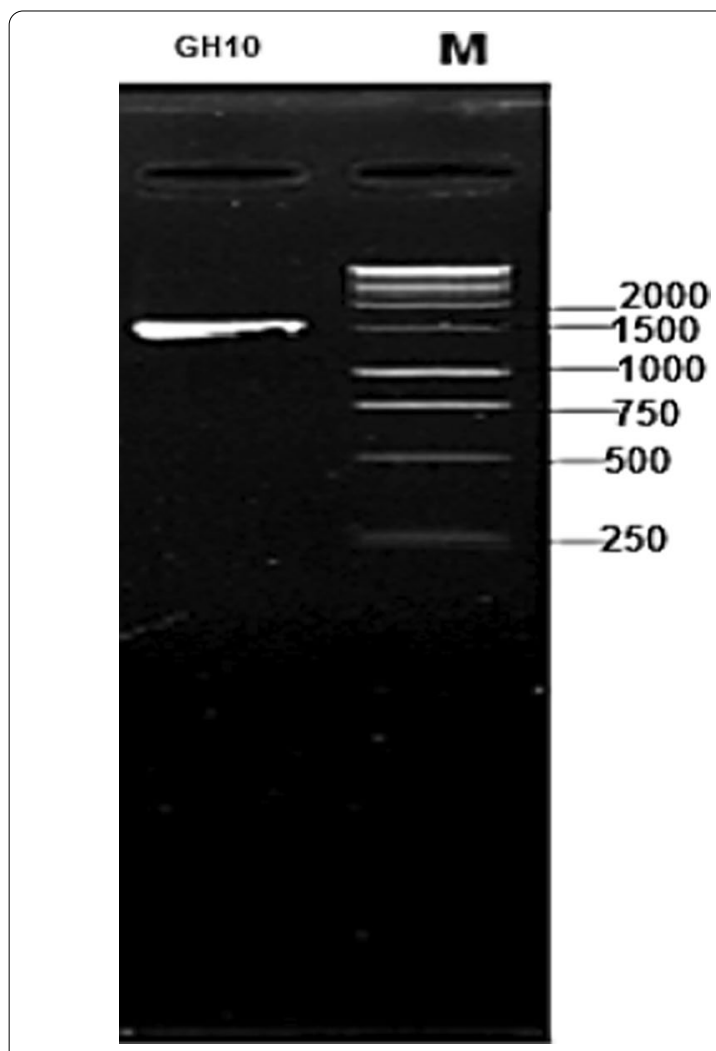

Fig. 1 Agarose gel electrophoresis for PCR product of $16 \mathrm{~s}$ rDNA gene in bacterial isolate M: $1 \mathrm{~Kb}$ DNA ladder (Thermo scientific)

significant reduction in the nematode reproductive parameters (Table 1). It was observed that NPK single treatment reduced $M$. javanica juveniles in soil by $57.5,66.8$ and $73.8 \%$ at planting time, after one and 2 months, respectively than the untreated control. The percent reductions in number of galls were found to be $62.6,64.7$ and $72.0 \%$ at the same time intervals, respectively. For egg masses, the number was found to be 61.6, 66.1 and $70.1 \%$ respectively, than the untreated control.

Concerning A. chroococcum Az single treatment, the percent reduction of $M$. javanica juveniles in soil compared to the untreated control plants ranged 64.9, 70.5 and $77.7 \%$, respectively. The respective number of galls was reduced by $65.6,68.6$ and $69.6 \%$. Similarly, the number of egg masses decreased by $61.6,66.2$ and $70.1 \%$.

For B. wiedmannii NRC211 Bw single treatment, the percent reduction of $M$. javanica juveniles in soil compared with the untreated control, ranged from 71.8, 75.0 and $78.0 \%$, respectively. While, the respective number of galls was reduced by $68.9,70.2$ and $72.6 \%$. The egg masses were similarly reduced by $67.2,70.6$ and $74.6 \%$. Similar patterns in percent reduction of nematode reproductive parameters were observed by frequent application of combined treatments with the bio agents i.e. increased percent reduction was correlated with the frequency of application, as shown in (Table 1).

It is noted that $\mathrm{Az}$ plus $\mathrm{Bw}$ treatment overwhelmed all other treatments in controlling nematode reproductive parameters with percentage reductions of 94.8, 79.0 and $80.1 \%$ in M. javanica juveniles in soil, galls and egg masses, respectively, followed by the application of $\mathrm{NPK}+\mathrm{Az}+\mathrm{Bw}$ treatment, which induced significant $(P \leq 0.05)$ reduction 73.2 and $74.6 \%$ in $M$. javanica galls and egg masses, respectively, compared to the untreated control. However, single application of either NPK, or $\mathrm{Az}$, or Bw produced significant reduction by $72.0,69.6$, $72.6 \%$, in galls number, respectively than the untreated control (Table 1).

\section{Effects on peanut crop production}

Concerning the effect of frequent applications of single or combined bio agents on peanut production, the recorded data indicated that the peanut production increased with increasing frequency of application in all treatments (Table 2). Thus, NPK single treatment increased peanut yield by $117.4,363.0$ and $634.8 \%$, respectively than the control. Application of $\mathrm{Az}$ single treatment increased peanut yield production to 39.1, 165.2 and $330.4 \%$, respectively than the untreated control. Moreover, by $B$. wiedmannii NRC211 single treatment, the yield increased by $39.1,108.7$ and $273.9 \%$, respectively than the untreated control.

In addition, obtained data revealed that cumulative effects of bioagents resulting from repeated application produced significant increase in peanut yield than the untreated control. Microbial fertilizer NPK single treatment produced the highest peanut yield of $634.8 \%$ as well as $608.7 \%$ for the combined application of NPK $+\mathrm{Az}$ compared to the untreated control. However, non- significant difference was found in the peanut yield between the application of either NPK alone or NPK + Az. While $497.8 \%$ increase was recorded due to the combined application of NPK $+\mathrm{Az}+\mathrm{Bw}$ (Table 2).

\section{Effects on peanut growth parameters}

Data in Table 2 revealed that all peanut growth parameters were increased in both single and combined treatments. In NPK single or combined treatments, significant percentage of increase in the number of pods was estimated than the untreated control. Moreover, the data indicated that frequent application of NPK single treatment increased weight of 200 seeds by $0.0,31.8$ and $65.9 \%$, respectively, than the control. As for Az single treatment, the percentage increase in the number of pods ranged from 126.0, 191.3 and $256.5 \%$, respectively, than the control. Also, Az single treatment produced 


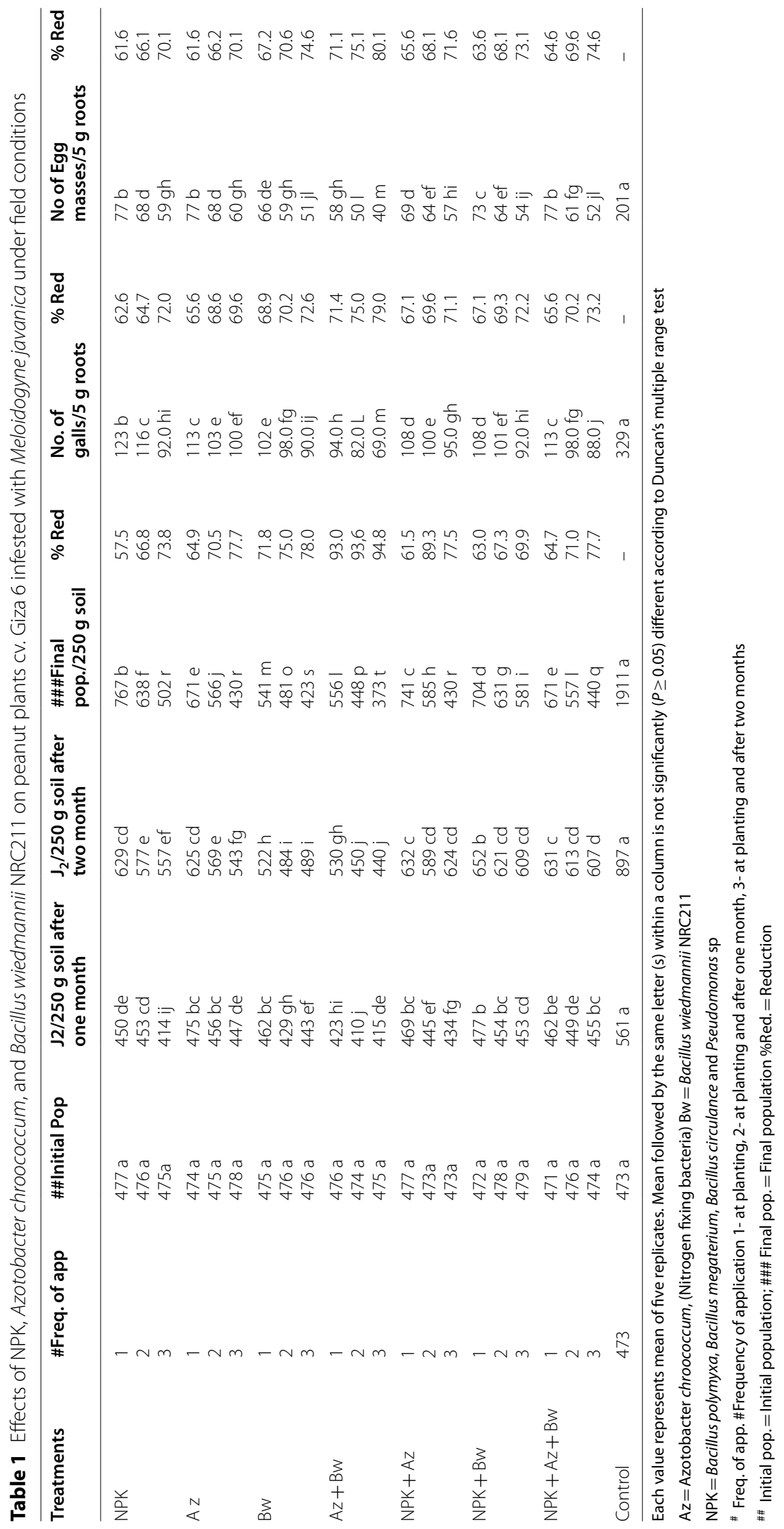




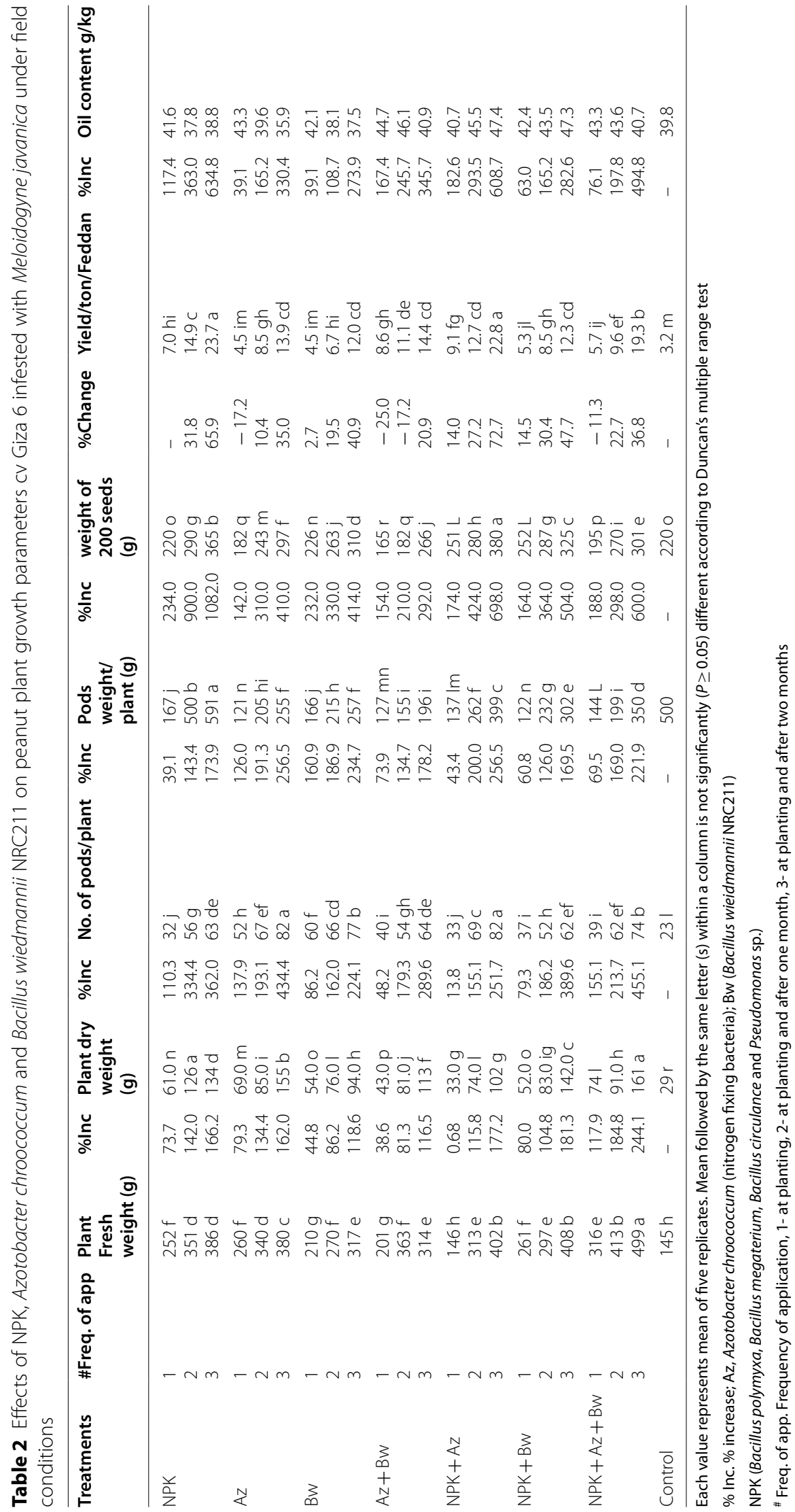


variations in weight of 200 seeds by 17.2, 10.4 and 35.0\%, respectively, than the control. Concerning $\mathrm{Bw}$ single treatment, pod number was increased by $160.9,186.9$ and $234.7 \%$, respectively and of $2.7,19.5$ and $40.9 \%$ in 200 seeds weight, compared to the control (Table 2).

Application of $\mathrm{NPK}+\mathrm{Az}+\mathrm{Bw}$ combined treatment produced the greatest percentage of increase 244.1 and $455.1 \%$ in fresh and dry weight of peanut plant, respectively, than to the untreated control, followed by $434.4 \%$ increase in dry weight for Az single treatment. Whereas, the application of NPK combined with Bw resulted in $181.3 \%$ increase in fresh weight than the control. Moreover, single application of NPK produced the highest level in pods weight $1082.0 \%$. In addition, the highest increase in the weight of 200 seeds was observed in the combined application of both NPK $+\mathrm{Az}$ (72.7\%) than the control. Furthermore, the applications of Az either single or combined with NPK recorded the highest percentage increase by $256.5 \%$ for each in the number of pods than the control (Table 2).

\section{Effects of bio agents on oil content of peanut seeds}

Concerning the effects of frequent application of bio agents either single or combined on oil percentages, the data in (Table 2) clearly showed that the oil content of seeds only increased with increasing the frequency of the application of NPK combined with either Az and/or Bw.

\section{Discussion}

Rhizospheric microorganisms e.g. plant growth promoting rhizobacteria (PGPR) maintain a close microenvironment around the root of plants that improve plant growth through various mechanisms like $\mathrm{N}_{2}$ fixation, solubilization of mineral phosphates and other essential elements (Abd-El-Khair et al. 2019). They play a key role in natural ecosystems and influence plant productivity, plant nutrition uptake and inhibition of plant pathogens (Osman et al. 2020). Bacterial strains showing PGPR activity included: Azotobacter, Bacillus and Pseudomonas (Bashan and de Bashan 2005). The present study was conducted to assess the efficacy of 3 bacterial bio- agents viz: NPK as standard microbial fertilizer, $A$. chroococcum as nitrogen fixing bacteria, and B. wiedmannii NRC211, as an organism of $B$. cereus group, isolated from the experimental field and applied singly or in combination for the management of root knot nematode $M$. javanica and on the growth and yield production of the peanut ( $A$. hypogaea L.) under field conditions.

Application of the microbial fertilizer NPK containing B. polymyxa, B. megaterium, B.circulance and Pseudomonas sp. A. chroococcum, a nitrogen fixing bacteria and B. weidmannii NRC211 singly or combined in soil naturally infested with $M$. javanica recorded variable significant reductions in nematode developmental parameters with considerable increase in yield production and oil content. These data agree with previous studies on beneficial microorganisms in controlling plant pathogens and enhancing crop production (Moslehi et al. 2021). The nematicidal activity of these bacterial agents might be due to secretion of antimicrobial compounds.

In a study on nematicidal effects of some strains of $B$. polymyxa, $B$. megaterium and $B$. circulance, the results indicated that the bacterial biofertilizers were promising double- purpose microorganisms for mobilizing of soil nutrients and for the biological control of M. incognita (Moslehi et al. 2021). Ann (2013), reported that antimicrobial metabolites and enzymes from Bacillus spp. exhibit high antagonistic effect against Meloidogyne spp. The present results go in the same direction with the findings of (El Deriny 2016) with respect to microbial activity. Thus, $B$. megaterium showed an enhance the incorporation of organic matter that activate antibiosis towards the nematode activity.

Osman et al. (2011) revealed that $P$. fluorescens significantly reduced $M$. incognita reproductive parameters associated with improving in eggplant growth and also increased activity of 3 enzymes; peroxidase, polyphenol oxidase and chitinase in treated plants compared to non-treated control. They concluded that $P$. fluorescens might induce systemic resistance in eggplant against $M$. incognita.

The present investigation indicated that combined treatment of $A$. chroococcum $+B$. wiedmannii NRC211 gave the greatest reduction in nematode reproductive parameters than the control. The nematicidal activity of these bacterial agents might be due to the ability of the rhizobacteria $B$. wiedmannii to produce the proteolytic enzyme protease. This explanation is in harmony with ElWakeel et al. (2020) on their study on Bacillus cereus as bio control agent against root knot nematode $M$. incognita infecting Solanum lycopersicum. In this regard, the proteolytic activity of $B$. wiedmannii strain assayed in the experiments, to be $1.17 \mu \mathrm{g}$ tyrosine $/ \mathrm{min} / \mathrm{ml}$ of the culture extract. It is well known that the entire surface of plant parasitic nematodes is covered by a multilayered cuticle. Cuticle degradation could be an effective way of controlling parasitic forms of root knot nematodes.

B. cereus is known as the source of several exotoxins and antibiotics, some of which have been reported to be nematicidal (Cawoy et al. 2011). The mechanism of nematode suppression by bacteria includes production of secondary metabolites that induce plant defense mechanisms Obtained results evidently indicated that application of $\mathrm{NPk}+A$. chroorcoccum $+B$. wiedmannii produced the highest peanut plant fresh and dry weight than the control. The present data is in harmony with 
the reports that integration of two or more nematicidal components gave better results in increasing sugar beet fresh and dry weight in soil infested with M. incognita than single treatments (Mostafa et al. 2018). Moreover, the present data indicated that application of $A$. chroococcum $+B$. wiedmannii recorded the highest reduction in $M$. javanica reproductive parameters. In addition, they obviously indicated that treatment of NPK single treatment produced the best results in increasing pods weight, weight of 200 seeds and yield production. This could be attributed to the fact that NPK contains a mixture of 4 microbial species viz: $B$. polymyxa, $B$. megaterium, B. circulance and Pseudomonas sp. Each one of these microbial strains has its own nematicidal mechanisms as well as its plant growth promoting effects as previously mentioned (Moslehi et al. 2021). Moreover, $A$. chroococcum either single or combined with NPK treatments showed the greatest increase in number of pods, in addition $\mathrm{NPK}+\mathrm{Az}$ combined treatment exhibited significant increase in pods weight, weight of 200 seeds, peanut crop production and oil content. This result is in harmony with the finding of Akram et al. (2016) who indicated that the application of A. chroococcum singly or combined with Glomus fasciculatum significantly increased growth parameters of chickpea plant infected with $M$. incognita than the control. These results could be discussed on the basis that soil bacteria Azotobacter, has been reported to produce growth promoting substances as auxins, cytokine, gibberellins and these bioactive compounds stimulate plant growth. These substances, which originate from the root surface, affect the growth of the closely associated higher plants (Wani et al. 2013).

Furthermore, the present study indicates that the efficacy of the bacterial bio agents in controlling nematodes depended upon the frequency of application. These results agree with El-Nagdi and Abd-El-Khair (2019) who revealed that, Bacillus sp., B. subtilis, or B. pumilus used more than once or in combination were more effective than those used once in reducing $M$. incognita reproductive parameters. There has been evidence that inoculation of crop plants with plant growth promoting rhizobacteria strains at an early stage of development improves biomass production through direct effects on root and shoot growth as well as enhancing the seedling germination, stand health, nutrient content of shoot tissues and nodulation in legumes (Dey et al. 2004 and Saharan and Nehra 2011).

Concerning the oil content of peanut seeds, increased levels were observed following combined treatments of $\mathrm{NPK}+$ either Az or Bw. However, incremental increase in oil content was not found in other single treatments. Increased increments of oil production as a result of combined application of nitrogen fixative bacteria and other bio agents are not surprising. It is well known that nitrogen as well as other nutrients is important for induction of enzyme proteins essential for fatty acid biosynthesis. On the other hand, application of single treatment of NPK, $A z$ or Bw might not be sufficient for induction of lipogenesis, which was negatively reflected on the oil content. Thus, it could be suggested that combined application of bio agents might have synergistic effects necessary to induce fatty acid biosynthesis in peanut seeds. This result needs to be further studied to fully elucidate its underlying biochemical mechanism.

\section{Conclusions}

From the previous results and discussion, it could be concluded that B. wiedmannii NRC211, isolated from peanut field and identified for the first time in the present study, is an eco-friendly microbial bio agent that could be applied with other commercial candidates such as NPK, A. chroococcum in the safe management of $M$. javanica infecting peanut fields and increasing crop yield without chemical nematicides. This could be achieved by repeated selected doses starting from planting time. However, more investigations are still required to elucidate the synergistic mechanisms of these bio-agents and determine their proper economical dosage forms.

\section{Abbreviations \\ NPK: A standard microbial fertilizer containing four microorganisms viz; Bacil- lus polymyxa, Bacillus megaterium, Bacillus circulance and Pseudomonas sp. It was purchased from a commercial office of the Ministry of Agriculture, Giza Egypt; Az: Azotobacter chroococcum commercial liquid preparation purchased from a commercial office of the Ministry of Agriculture, Giza Egypt.; Bw: Bacil- lus wiedmannii NRC211 rhizobacterium was isolated from soil samples adher- ing to peanut plant from the previous peanut crop in the same experimental field. Identification was done through PCR amplification and sequencing of 16 s rDNA gene..}

\section{Acknowledgements \\ None.}

Authors' contributions

Experimental design was performed by HAO, HHA, MM, USE; Carried out the experiment and collecting data were performed by MM, USE; Data analyses was performed by $\mathrm{HHA}$; Collecting of review was performed by $\mathrm{HAO}, \mathrm{HHA}$; Molecular analyses were performed by GME; Analyses of oil content was performed by MGD; The manuscript was written by HAO. The authors read and approved the final manuscript.

Funding

Not applicable.

Availability of data and materials

All data and materials are mentioned in the manuscript.

\section{Declarations}

Ethical approval and consent to participate Not applicable. 


\section{Consent for publication \\ Not applicable.}

\section{Competing interests}

The authors declare that they have no competing interests.

\section{Author details}

${ }^{1}$ Plant Pathology Department, National Research Center, Giza, Egypt. ${ }^{2}$ Microbial Genetic Department, National Research Center, Giza, Egypt. ${ }^{3}$ Botany Department, National Research Center, Giza, Egypt.

Received: 28 June 2021 Accepted: 11 September 2021

Published online: 27 September 2021

\section{References}

A O A C Official methods of analysis 20th edition. Arlington, Virginia: Association of Official Analysis Chemists

Abd-El gawad MMM (2014) Yield losses by phytonematodes: challenges and opportunities with special reference to Egypt. J Agronematol 13(1):75-94

Abd-El-Khair H, El-Nagdi WMA, Youssef MA, Abd-Elgawad MMM, Dawood MG (2019) Protective effect of Bacillus subtilis, B. pumilus, and Pseudomonas fluorescens isolates against root knot nematode Meloidogyne incognita on cowpea. Bull Nat Res Centre 43:64. https://doi.org/10.1186/ s42269-019-0108-8

Akram M, Rizivi R, Sumbul A, Ansari RA, Mahmood I, Marol TM (2016) Potential role of bioinoculants and organic matter for the management of rootknot nematode infesting chickpea. Congent Food Agric 2(1)

Ann YC (2013) Screening for nematicidal activities of Bacillus species against root knot nematode (Meloidogyne incognita). Am J Exp Agric 3:794-805

Atlas RM (1995) The handbook of Microbiological Media for the Examination of Food. CRC Press, Bocc Raton, p. 197. Biolgy 120:487-492

Bansal RK, Verma VK (2002) Antagonistic efficacy of Azotobacter chroococcum against Meloidogyne javanica infecting bringal. Indian J Nematol 32:132-134

Barker TR (1985) Nematode extraction and bioassays pp. In: Barker YR, Carter CC, Sasser JN (eds) An advanced Treatise on Meloidogyne, vol 11. North Carolina State University, Raleigh, pp 19-35

Bashan Y, de Bashan LE (2005) Bacteria/plant growth promotion. In: Hillel $\mathrm{D}$ (ed) Encyclopedia of soils in the environment. Elsevier, Oxford, pp 103-115

Cawoy H, Bettiol W, Fickers P, Orgena M (2011) Bacillus- based biological control of plant diseases. In: Stoytcheva M (Ed.), Pesticides in the modern world- pesticides use and management. In Tech, Rijeka, pp 273-302

Davis RW, Botstein D, Rotho JR (1980) Transfection of DNA. In bacterial genetics: a manual for genetic engineering advanced bacterial genetic, Vol 67. Cold Spring Harbor Lab Cold Spring Harbor New York 67:134-137

Dey R, Pal KK, Bhatt BM, Chauhan SM (2004) Growth promotion and yield enhancement of peanut (Arachis hypogaea L.) by application of plant growth-promoting rhizobacteria. Microbiol Res 159:371-394

Duncan DB (1955) A significant test for differences between ranked treatments in analysis of variance. Verginia J Sci 2:171-189

El-Derinny MM (2016) Integrated control of certain plant parasitic nematodes infecting curcubitacae plants. Ph.D. Thesis. Faculty of Agric., Mansoura, University, Egypt, p 156

El-Nagdi WMA, Abd-El-Khair H (2019) Application of Bacillus species for controlling root-knot nematode Meloidogyne incognita in eggplant. Bull Natl Res Centre 43:154. https://doi.org/10.1186/s42269-019-0187-6

El-Sayed GM, Nivien AA, Ibrahim SA, Abd-Elrazik AB, Hammad MA, Hafez FM (2018) Identification of gene encoding organophosphorus hydrolase $(\mathrm{OPH})$ enzymein potent organophosphorus degrading bacterial isolates. J Environ Sci Technol 11:175-189
El-Wakeel AM, El-Nagdi MAW, Soliman MG, Elkelany US (2020) Dwal management of root-knot nematode Meloidogyne incognita and weeds infested solanum lycopersicum with protoplast fusants of Bacillus cereus and Pseudomonas aeruginosa. Plant Archives 20(2):9133-9143

Han X, Damodaran S (1997) Isolation, Identification, and fermentation of Bacillus species producing a detergent- stable endopeptidase. J Agric Food Chem 45(11):4191-4195

Hasseb A, Khan MR (2012) Prospects of Trichoderma in nematode management. In: Nagesh M, Rajkumar BS, Bhumannavar NK, Krishna Kumar (eds) Status and prospects for enhancing the uptake of antagonistic organisms for nematode management in India. NBA11 (ICAR), Bangalore, India, pp 187

Ibrahim KAl, Mokbel AA (2009) Occurence and distribution of the root-knot nematodes Meloidogyne spp. and their host plants in northern Egypt. J Exp Biol (bor) 5:125-129

Khan MR, Singh RV, Pramank A (2010) Economically important plant parasitic nematodes distribution. ATLAS. Indian Council of Agricultural Research, New Delhi, p 137. https://www.iari.res.in/titles/atlases.pdf.

Moosavi MR, Zare R (2012) Fungi as biological control agents of plant parasite nematodes. Prog Biol Control 12:67-107

Moslehi S, Pourmehr S, Shirz A, Khakvar R (2021) Potential of some endophytic bacteria in biological control of root- knot nematode Meloidogyne incognita. Egypt J Biol Pest Control 31(50):2021. https://doi.org/10.1186/ s41938-021-00396-4

Mostafa FAM, Khalil AE, Nour El-Deen AH, Ibrahim DS (2018) The role of Bacillus megaterium and other bio-agents in controlling root- knot nematodes infecting sugar beet under field conditions. Egyptian J Biol Pest Control 28:1-6

Osman HA, El-Gindi AY, Youssef MMA, Ameen HH, Abd-Elbary NA, Teixeira da Silva JA, Lashein AMS (2011) Protection of Pseudomonas fluorescens against the root-knot nematode, Meloidogyne incognita; role of enzymeinduced resistance in eggplant. Pest Tecc Global Science Books, pp 44-47

Osman HA, Ameen HH, Moawad M, Elshahawy IE, Elkelany US (2019) Comparative effects of some natural eco. Friendly biofertilizer with the nematicide oxamyl on suppression of root knot-root rot complex diseases infecting peanut plants under field conditions. Middle East J Agric 8(2):371-381

Osman HA, Ameen HH, Moawad M, Elkelany US (2020) Efficacy of integrated microorganisms in controlling root knot nematode Meloidogyne javanica infecting peanut plants under field conditions. Bull Nat Res Center 44:134-143

Puntener W (1981) Manual for field trials in plant protection. Basel, Switezerland Agricultural Division, Ciba Geigy Limited, 205

Saharan BS, Nehra V (2011) Plant growth promoting rhizobacteria: a critical review. Life Sci Med Res 21:1-33

Siddiqui ZA, Mahmood I (2001) Effects of Rhizobacteria and root symbionts on the reproduction of Meloidogyne javanica and growth of chickpea. Bioresour Technol 79:41-45

Snedecor GW, Cochran WG (1980) Statistical methods, 7th edn. lowa State University Press, lowa, p 507

Taylor AL, Sasser JN (1978) Biology, identification and control of root nematodes (Meloidogyne species). IMP. North Carolina State University Graphics, Raleigh (NC)

Vejan P, Abdullah R, Khadiran T, Ismail S, Nasrulhaq Boyce A (2016) Role of growth promoting rhizobacteria in agricultural sustainability - a review. Molecules 21(5):573. https://doi.org/10.3390/molecules21050573

Wani SA, Shand S, Ali T (2013) Potential use of Azotobacter chroococcum in crop production: an over view. Current Agric Res J 1:35-38

\section{Publisher's Note}

Springer Nature remains neutral with regard to jurisdictional claims in published maps and institutional affiliations. 